\title{
TTR
}

Traduction, terminologie, re?daction

\section{David Katan. Translating Cultures, An Introduction for Translators, Interpreters and Mediators. Manchester, St. Jerome Publishing, 1999, 271 p.}

\section{Rosalind Gill}

Volume 12, numéro 1, 1er semestre 1999

Poésie, cognition, traduction I

Poetry, Cognition, Translation I

URI : https://id.erudit.org/iderudit/037360ar

DOI : https://doi.org/10.7202/037360ar

Aller au sommaire du numéro

Éditeur(s)

Association canadienne de traductologie

ISSN

0835-8443 (imprimé)

1708-2188 (numérique)

Découvrir la revue

Citer ce compte rendu

Gill, R. (1999). Compte rendu de [David Katan. Translating Cultures, An Introduction for Translators, Interpreters and Mediators. Manchester, St. Jerome Publishing, 1999, 271 p.] TTR, 12(1), 193-196.

https://doi.org/10.7202/037360ar d'utilisation que vous pouvez consulter en ligne.

https://apropos.erudit.org/fr/usagers/politique-dutilisation/ 
David Katan. Translating Cultures, An Introduction for Translators, Interpreters and Mediators. Manchester, St. Jerome Publishing, 1999, 271 p.

This is a book about translating culture in a globalized world. The author provides an overview of the various theories of culture that may be used by translators and interpreters in their struggle to translate across cultures. Here, the pervasive and oft times evasive role of culture is given its rightful place as central to the translation process. The author's stated purpose is that the book serve as a framework for teaching culture in translation courses. While the book has its merits, it raises, in my mind, questions regarding definitions of knowledge and the scope of university training for translators.

Highly interdisciplinary in its approach, the book touches on theories of communication ranging from anthropology, sociology, sociolinguistics, philosophy, to psychology. Bandler and Grinder's Neuro Linguistic Programming (NLP), a meta-model theory of how we structure experience, is reviewed in some depth. Examples discussed, largely drawn from international trade and political situations, show how the translator could use the NLP notions of meta-message and framing to perform an "out-of -awareness" cultural reading of a text or 
situation. According to the notion of "out-of-awareness" understanding, the translator uses framing to read a text and "accesses grouped linguistic and textual knowledge". What is questionable here is the notion that the use of set categories allows the translator to "access knowledge". Such packaging of knowledge falls in line with trends in this globalized world, where there is pressure on universities to produce information-packaged formula for "professionally-oriented" curricula, in which students "access knowledge" in located places. The author gives credit to the influence of anthropologist Gregory Bateson's epistemology (logical typing, frames, mapping) in the development of NLP notions of framing. But if we go back to Bateson's writing on the ecology of communication, we will see that Bateson did not believe that knowledge can be "accessed" or that cognition can be reduced to levels of logical category. In fact, Bateson stressed that communication emerges in multiple changing patterns at multiple relational levels. Cognition is intimately related to perception which is, in turn, related to the social relationship between speakers. Bateson insistently pointed out the dangers of jumping from the epistemological to the practical and the confusion that can arise from mistaking data for knowledge.

There is no doubt that the presentation of culture as a "system for orienting experience" and the description of ways of framing cultural perception, especially the examples provided in Translating Cultures, could be very useful in helping students develop awareness and expertise in translating culture at the beginning of this new millennium. However, the teacher instructing translators in a university setting should make the students aware that categories and frames must be seen for what they are and care should be taken to avoid using these models in a reductionist manner. Isomorphic matching of cultural situations to theoretical frames of reality can lead to superficial or inadequate solutions and do not necessarily constitute cultural understanding.

The reader interested in current theories of culture will find Katan's overview of the various approaches informative, detailed and exhaustive. Models for culture and perception of reality are systematically placed in their intellectual context. Background is provided on Bateson, Halliday, Sperber and Wilson, Edward Hall and many others. The book is also extremely well organized, ideas are 
presented in point-form at the beginning of each chapter, and useful tables and comparative lists abound. However, in this comprehensive theoretical sweep, the reader gets the sensation of hopping from one school of thought to another. A student reading the book would certainly be daunted by the frequent use of quotes, build-up of multiple references to models and juggling of theoretical terminology. Another pitfall of such a broad overview is a tendency to generalize or quote out of the fullness of context. I think, for example, of the section on local translating $(\mathrm{Ch} .8,8.1)$ in which a reference to Wilson and Sperber's relevance theory as it applies to cognitive effort and processing leads to the following statement at the end of the paragraph: "It is quite possible that local translating actually involves more cognitive effort than global translating." There is no further elaboration and the reader is left dangling.

Throughout the book, the various categories, hierarchies and levels that are suggested as possible templates for mapping cultural experience are exemplified by authentic situations of cultural misunderstanding and ensuing translation problems. The examples provided display the author's rich understanding of the implicit and powerful role of cultural assumptions, patterns and values. Indeed the wealth and variety of examples constitute the great strength and joy of this book. Citing situations from the world of literature, business or politics, the author displays a profound sensitivity to cross-cultural communication and a keen expertise in teaching students how the powerful subtlety of cultural perception, if not accounted for, can lead to bad translation. A number of possible solutions are put forth for each given cultural translation dilemma, then a detailed analysis of the appropriateness of the solutions is provided. These case studies, which exemplify with great clarity the specific point being made, are a valuable pedagogical tool for the teaching of the cultural element of translation.

One last point : the author makes a case for the translator or interpreter to become a cultural mediator, and provides some very helpful hints for interpreters as to how they can advise clients of possible cross-cultural miscommunication before negotiation even begins. This is useful advice on the practical level, but again, I firmly believe that professors teaching university students to become proficient cultural mediators must go beyond this. They must lead the 
students into an exploration of the whole notion of cultural understanding. The different ways of perceiving the intention of, objective of, value of, or belief in, cultural mediation needs to be included in the curriculum as another level of framing. Examples in the book from the world of business and trade clearly define cultural differences as an obstacle to profit (as in the fascinating example of the cultural problems arising from using McDonald's performance evaluation sheets in non-American cultures). In such a situation, the prime purpose of the cultural mediation is to resolve a business problem. In this case, the translation professor should help the students explore the ideology of the translator/interpreter's professional objectives, compare this case to other cross-cultural situations, past and current, and develop full awareness of context of the activity.

As teachers, we must not lose sight of the fact that profound cultural experience grows out of profound education. The teacher using Translating Cultures to teach about culture should be wary of the danger of confusing frames for perception of reality and the full depth of reality itself. Above and beyond training in professional skills, the translation student must be cultivated, well-grounded in the humanities and aware of the profound social, human ramifications of being a cultural mediator. As teachers, we must always frame the frames.

\section{Rosalind Gill Glendon College, York University}

